\title{
THE INTERIOR IN SCHOOL BUILDINGS. DIMENSIONS AND SCALES OF THE ELEMENTS OF INTERIOR REQUIREMENTS FOR ELEMENTS OF THE INTERIOR SPACE
}

\author{
Elitsa Ivanova Ch. Assist. Prof. Dr. Arch \\ University of Architecture, Civil Engineering and Geodesy, Sofia, Bulgaria
}

DOI: https://doi.org/10.31435/rsglobal_ws/30062019/6560

\section{ARTICLE INFO}

Received: 14 April 2019

Accepted: 18 June 2019

Published: 30 June 2019

\section{KEYWORDS}

School buildings interior, children's characteristics in various age groups, furniture, design, children, chairs, chairs for children, tables for children, new trends, materials, colours, age. \begin{abstract}
Ergonomic requirements for furniture are defined.

Dependency between the physiological characteristics of children and the size of furniture and spaces are followed up in the article.

The main trends for design of classroom furniture are provided.

Materials required to create furniture for particular age groups of students are indicated.

Materials for finishing layers of the enclosing elements have been identified, specifying their characteristics and when these are the most apprpriate to achieve a better learning environment.
\end{abstract}

Citation: Elitsa Ivanova. (2019) The Interior in School Buildings. Dimensions and Scales of the Elements of Interior Requirements for Elements of the Interior Space. World Science. 6(46), Vol.1. doi: 10.31435/rsglobal_ws/30062019/6560

Copyright: (C) 2019 Elitsa Ivanova. This is an open-access article distributed under the terms of the Creative Commons Attribution License (CC BY). The use, distribution or reproduction in other forums is permitted, provided the original author(s) or licensor are credited and that the original publication in this journal is cited, in accordance with accepted academic practice. No use, distribution or reproduction is permitted which does not comply with these terms.

The concept of physical development synthesises on the one hand the growth or the quantitative increase of the basic dimensions of the body characteristic of the full-term newborn baby and, on the other hand, the development or maturation - the appearance and changes of the physical parameters that the child's organism should acquire at a certain age. The growth rate and parameters that the body reaches in a particular age group are the basis of the design and production of furniture for school buildings interior. To be comfortable it should be ergonomic.

The term ergonomics comes from the Greek words ergon (work) and nomos (rule) and means science of human work/labour. Ergonomics is a science that studies the compliance of the environment with the human body and the reduction of fatigue and discomfort by designing such products. When it comes to furniture design, it has to be taken into account whether the designed products correspond to the needs of the people who use them. Whether at work, at school or at home, when products are user-friendly, the result is more comfort, higher productivity and less stress.

Interaction of human body with the tools of labour and furniture is of a key importance. When working at a desk, the main concern is for ergonomic sitting position, which is the physiologically optimal position that is not overtax and thus increases concentration and prevents back pain and headaches.

Principles of ergonomic sitting.

1. There is no such thing as proper and wrong sitting.

The only important thing is changing the posture frequently. So do not correct the posture of your child when he/she is taking a strange position on the chair.

2. The desk and chair should "fit" like a glove on the one who sits there.

In order to achieve a healthy sitting position, the working environment of the child should be compatible to his/her height and proportions. Adjustment starts with the chair, the second step is the height of the desk. 
3. The height of the chair should be chosen so that the front edge of the seat is approximately at the level of the rear of the knee. The height of the seat is correct when the angle between the hip and the body is slightly above $90^{\circ}$ and the feet are firmly on the floor. Tilting the seat forward encourages the child to sit upright and concentrate while working at the desk. The pelvis is slightly tilted forward and the back is upright. The removable seat supports dynamic sitting position.

4. The depth of the seat may be adjusted so that the hips rest on the front edge without tension. The distance between the front edge of the seat and the calf of the leg should be about 4 fingers. This ensures the free passage of blood through the legs.

5. The seat must be at such a height as to support the body from the pelvis to the shoulder blades. Thus, when leaning back pressure is released from the back.

6. In order to adjust the height of the desk, put your hands on top. The position is correct when the elbow angle is slightly above $90^{\circ}$.

7. The lower part of the arms should be resting while working. This is how the muscles of the neck rest.

When designing furniture it is very important to know that for different countries the parameters and dimensions of the human body are different.

Anthropometric measures.

Anthropometry is a science that measures the physical dimensions of a population. When products are designed, it is important to keep in mind that the human body has different sizes and shapes. Anthropometric data vary considerably between the populations of different countries.

Based on experience and numerous studies, conclusions have been drawn about the size and type of seating furniture required in different classrooms.

- Types of furniture in the classroom

For each classroom, regardless of the age group of students, the following furniture may be listed:

- Seating furniture - chairs for students, chair for the teacher;

- Tables and worktops - tables for students, worktops on the periphery, table for the teacher;

- Storage furniture - frame furniture - this group includes all types of bookcases, shelves, sectional furniture, cabinets, etc.;

- "Black" board - in modern school it is very often replaced by an interactive board, projection screen, or greenboard, but its main function is preserved, and so is its place.

Students' table and chairs should be considered together. In a classroom, desks are often used as a combination of a chair and table. Desks are intended for two students or there are one-seat desks for one student. Nowadays, desks are increasingly giving place to tables. Tables may also be intended for two or one student.

\section{- Furniture dimensioning}

One of the most accurate studies of the ratio between furniture dimensions and students' size according to their age was made by Prof. Ernst Neufert.

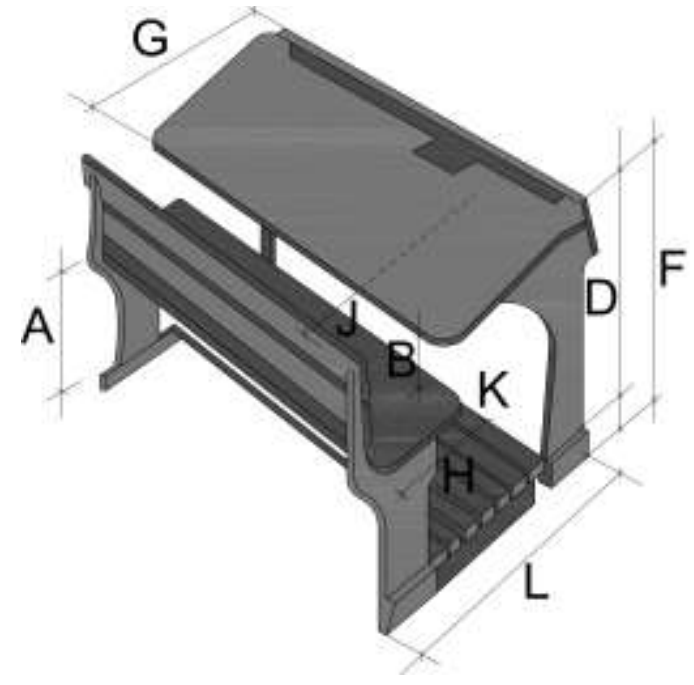

Fig.1. Dimensions of desks for two

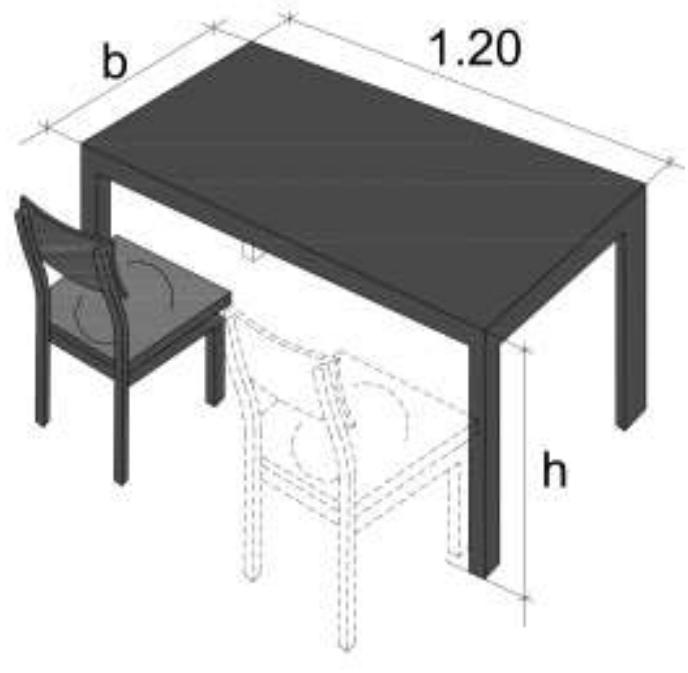

Fig.2. Dimensions of tables for two 
Table 1. Size of school desks /Prof. Ernst Neufert/

\begin{tabular}{|l|l|l|l|l|l|l|l|l|}
\hline $\begin{array}{l}\text { Under } \\
116\end{array}$ & $\begin{array}{l}116- \\
124\end{array}$ & $\begin{array}{l}124- \\
132\end{array}$ & $\begin{array}{l}132- \\
141\end{array}$ & $\begin{array}{l}141- \\
150\end{array}$ & $\begin{array}{l}150- \\
160\end{array}$ & $\begin{array}{l}160- \\
170\end{array}$ & $\begin{array}{l}\text { Above } \\
170\end{array}$ & Height of students \\
\hline 6 & $7-8$ & $8-9$ & $9-10$ & $10-12$ & $12-14$ & $14-16$ & $\begin{array}{l}\text { Above } \\
16\end{array}$ & Age /years/ \\
\hline 30.2 & 32.3 & 34.7 & 37.1 & 39.8 & 42.6 & 45.6 & 48.6 & A-height of the seat \\
\hline 19.5 & 20.6 & 21.9 & 23.2 & 24.6 & 26.0 & 27.6 & 29.2 & $\begin{array}{l}\text { B-edge of the board } \\
\text { above the seat }\end{array}$ \\
\hline 5.9 & 5.9 & 5.9 & 5.9 & 6.2 & 6.2 & 6.2 & 6.6 & $\begin{array}{l}\text { C-slope of the } \\
\text { board }\end{array}$ \\
\hline 55.5 & 58.7 & 62.5 & 66.4 & 70.6 & 75.0 & 79.8 & 84.5 & $\begin{array}{l}\text { D-full height } \\
\text { without the grate } \\
\text { under the feet }\end{array}$ \\
\hline 15.0 & 15.0 & 15.0 & 15.0 & 15.0 & 15.0 & 15.0 & 15.0 & $\begin{array}{l}\text { E-height of the } \\
\text { grate }\end{array}$ \\
\hline 70.5 & 73.5 & 77.5 & 81.4 & 85,6 & 90.0 & 94.8 & 99.5 & F-total height \\
\hline 35.0 & 35.0 & 36.0 & 37.0 & 38.0 & 39.0 & 40.0 & 41.0 & $\begin{array}{l}\text { G-width of the } \\
\text { writing board }\end{array}$ \\
\hline 24.0 & 24.0 & 25.5 & 27.0 & 28.5 & 30.0 & 32.0 & 34.0 & H-width of the seat \\
\hline 22.0 & 23.5 & 25.0 & 26.6 & 28.3 & 30.0 & 31.8 & 33.6 & $\begin{array}{l}\text { J-distance from the } \\
\text { back to the writing } \\
\text { board }\end{array}$ \\
\hline 1 & 1 & 1 & 1 & 1 & 1 & 1 & 1 & $\begin{array}{l}\text { K-overlapping of } \\
\text { the writing board } \\
\text { with the seat }\end{array}$ \\
\hline 62.3 & 63.8 & 66.3 & 68.9 & 72.3 & 74.9 & 77.6 & 80.3 & $\begin{array}{l}\text { L-total width of the } \\
\text { desk }\end{array}$ \\
\hline
\end{tabular}

Table 2. Size of school tables for two /Prof. Ernst Neufert/

\begin{tabular}{|l|l|l|l|l|l|l|l|l|}
\hline $\begin{array}{l}\text { Under } \\
116\end{array}$ & $116-124$ & $124-132$ & $132-141$ & $141-150$ & $150-160$ & $160-170$ & $\begin{array}{l}\text { Above } \\
170\end{array}$ & $\begin{array}{l}\text { Height of } \\
\text { students }\end{array}$ \\
\hline 56 & 60 & 66 & 71 & 74 & 76 & 78 & 78 & $\begin{array}{l}\text { h-total } \\
\text { height }\end{array}$ \\
\hline 45 & 50 & 50 & 55 & 55 & 55 & 60 & 60 & B-width \\
\hline 36 & 40 & 42 & 44 & 46 & 46 & 48 & 48 & $\begin{array}{l}\text { s-height of } \\
\text { the seat } \\
\text { from the } \\
\text { floor }\end{array}$ \\
\hline $33 \times 35$ & $35 \times 38$ & $35 \times 38$ & $37 \times 40$ & $37 \times 40$ & $40 \times 43$ & $40 \times 43$ & $40 \times 43$ & $\begin{array}{l}\text { Size of the } \\
\text { seat }\end{array}$ \\
\hline
\end{tabular}

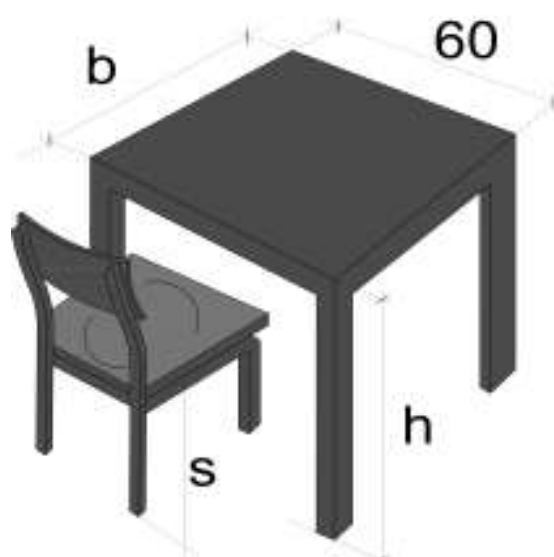

Fig.3. Size of school tables for one /Prof. Ernst Neufert/ 
Table 3. Size of school tables for one /Prof. Ernst Neufert/

\begin{tabular}{|l|l|l|l|l|l|l|l|l|}
\hline $\begin{array}{l}\text { Under } \\
116\end{array}$ & $116-124$ & $124-132$ & $132-141$ & $141-150$ & $150-160$ & $160-170$ & $\begin{array}{l}\text { Above } \\
170\end{array}$ & $\begin{array}{l}\text { Height of } \\
\text { students }\end{array}$ \\
\hline 56 & 60 & 66 & 71 & 74 & 76 & 78 & 78 & $\begin{array}{l}\text { h-total } \\
\text { height }\end{array}$ \\
\hline 45 & 50 & 50 & 55 & 55 & 55 & 60 & 60 & B-width \\
\hline 36 & 40 & 42 & 44 & 46 & 46 & 48 & 48 & $\begin{array}{l}\text { s-height } \\
\text { of the } \\
\text { seat from } \\
\text { the floor }\end{array}$ \\
\hline $33 \times 35$ & $35 \times 38$ & $35 \times 38$ & $37 \times 40$ & $37 \times 40$ & $40 \times 43$ & $40 \times 43$ & $40 \times 43$ & $\begin{array}{l}\text { Size of } \\
\text { the seat }\end{array}$ \\
\hline
\end{tabular}

The ratio between the student's height and classroom furniture is very important so that the student may study comfortably. Comfortable sitting reduces fatigue. Good furniture, suitably chosen for different age groups, helps in the formation of good posture and reduction of spinal deformities in children. It should be known that students spend most of the day at school.

\section{- Materials for making furniture}

Different groups of students use different size of furniture and often the material from which they are made is different.

Physiology and emotional state of children, striving for ergonomics and absolute comfort and safety are the leading factors in choosing the material. It is very important that the furniture is resistant to mechanical stress.

Table 4. Types of furniture for primary, secondary and high education classes /Photos published on the Internet/

\begin{tabular}{|l|l|l|}
\hline Furniture & Material for primary education classes & $\begin{array}{l}\text { Material for secondary and high education } \\
\text { classes }\end{array}$ \\
\hline $\begin{array}{l}\text { Table } \\
\text { on desk }\end{array}$ & $\begin{array}{l}\text { Plastic - easy maintenance, durable, lightweight, } \\
\text { variety of colours and models. A very good option } \\
\text { for the youngest students. }\end{array}$ & $\begin{array}{l}\text { Plastic - not commonly used material in its pure } \\
\text { form, i.e. if not combined with metal or wood. } \\
\text { Various plastic materials are used for new } \\
\text { conceptual models of multifunctional furniture. }\end{array}$ \\
& $\begin{array}{l}\text { Plastic furniture is safe, which makes them } \\
\text { preferred furniture. They are very light and the } \\
\text { children can move and arrange them. } \\
\text { Wood /solid wood, layered wood, pressed } \\
\text { chipboard, medium density fiberboard/ - gives } \\
\text { warmth and coziness. Robust, durable, with a } \\
\text { choice of colours. Most often, the natural colour } \\
\text { of wood is used. }\end{array}$ & $\begin{array}{l}\text { Wood /solid wood, layered wood, pressed } \\
\text { density fiberboard } \\
\text { chipboard, medium } \\
\text { (MDF)/ - less frequently used in its pure form, } \\
\text { i.e. if not combined with metal or wood. Most } \\
\text { often the chair is made entirely of wood and the } \\
\text { table is combined with metal. }\end{array}$ \\
\hline
\end{tabular}




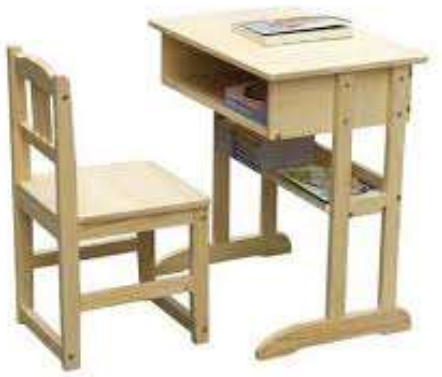

Combination of metal and wood - the best and most common combination. It has the strength of metal and the wood processing option.

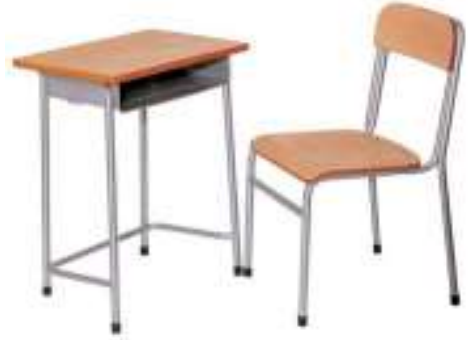

Combination of metal and plastic - increasingly replacing wood. Great colour variety, lightweight and durability. Brighter colours are selected.

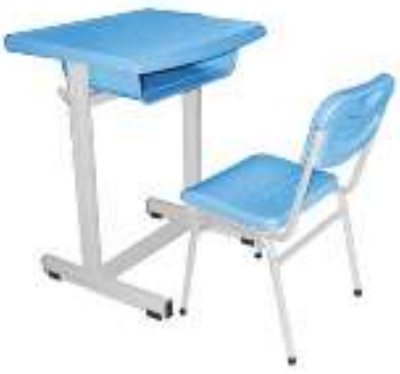

\section{Storage} furniture

frame furniture
Plastic - easy to maintain, durable, lightweight, with great variety of colours and models. These are rarely manufactured because of the larger size of the furniture.

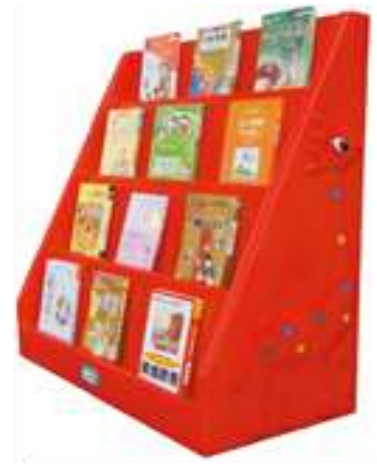

Wood - gives warmth and coziness. Easy and fast installation. Solid wood, layered wood, most often pressed chipboard and MDF panels may be used. The furniture is comfortable for use, safe and resistant to mechanical and atmospheric influences.
It is most commonly used for bookcases, shelves and racks.

Combination of metal and wood - the best and most common combination. Both the chair and table are combined with metal housing.

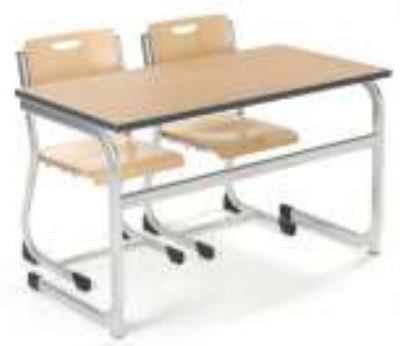

Combination of metal and wood increasingly replacing wood. Due to the larger size of the students, a higher strength of furniture is required; therefore, it is not relied on metal as supporting element.

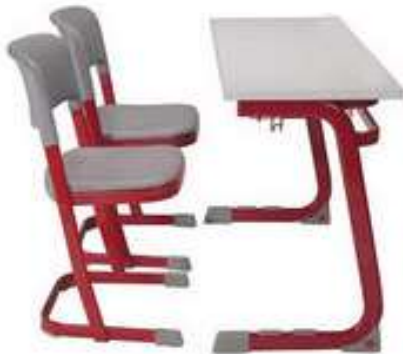

In this version, unlike the previous one, furniture is lighter, much more resistant to mechanical and atmospheric influences, easy to maintain and operate, and much cheaper.

Plastic - very rarely used. Most often, for boxes to store objects.

Wood - commonly used material for any framework furniture - with open shelves and bookcases or with closed sections. Solid wood, layered wood, most often pressed chipboard and MDF panels may be used.

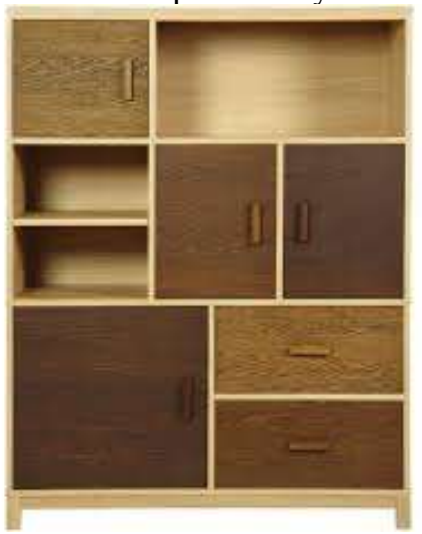




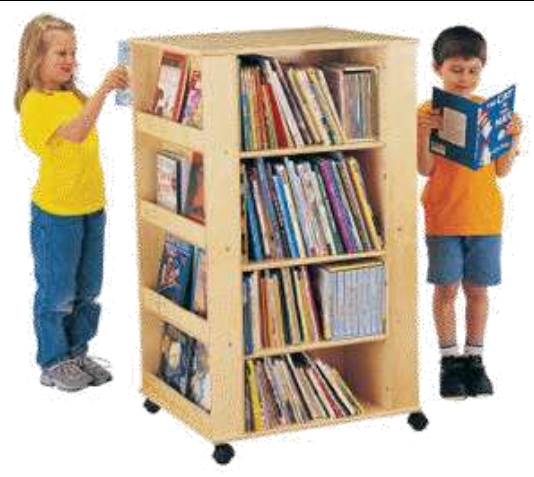

Metal and wood combination - the best and most common combination. Very often the wood is dyed or stained in a suitable color. Open furniture of high strength and durability is thus created.

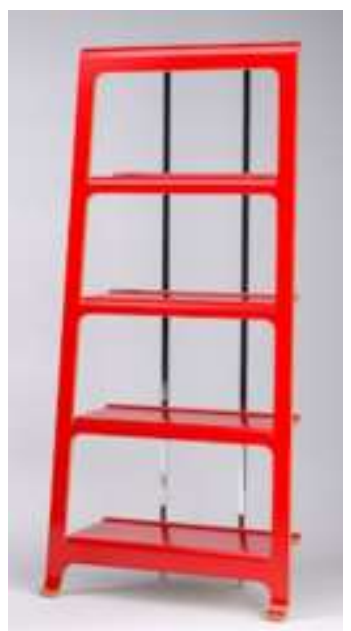

Metal and plastic combination - metal structure and plastic housings, or shelves, drawers, boxes.

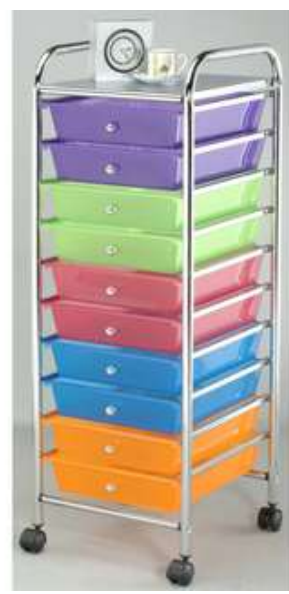

Wood and plastic combination - wide variety of options. Wooden base with plastic housing.
Metal and wood combination - the best and most common combination.

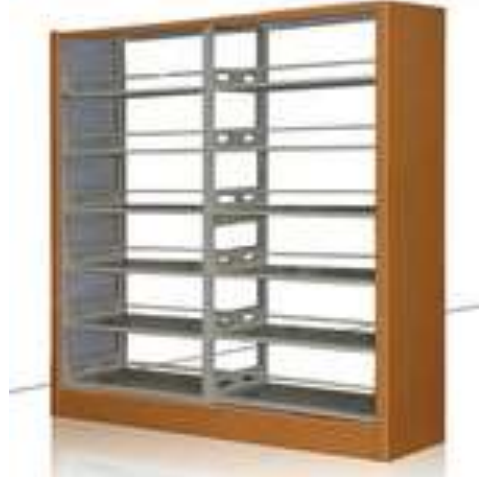

The strength of the metal construction and the lightweight wood is used, which results in coziness and comfort.

Metal and plastic combination - lightweight furniture with high mobility.

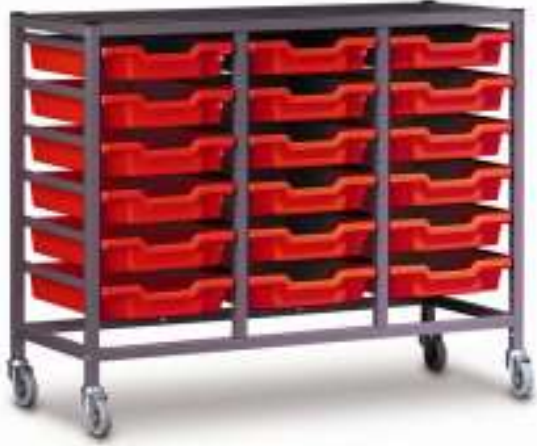

Wood and plastic combination combination of solid wood or wooden frames and plastic shelves, boxes and drawers.

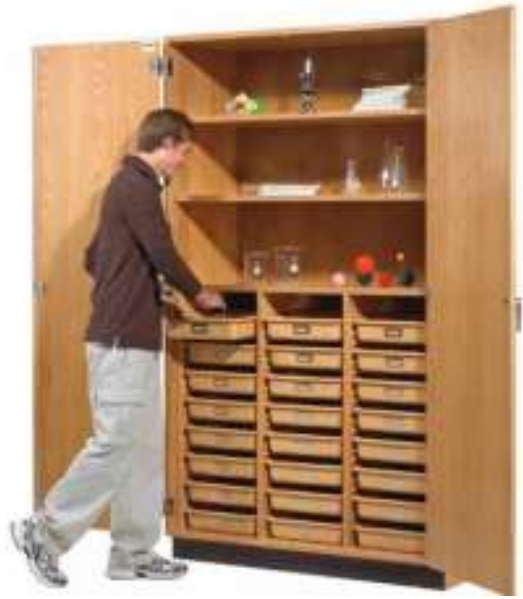




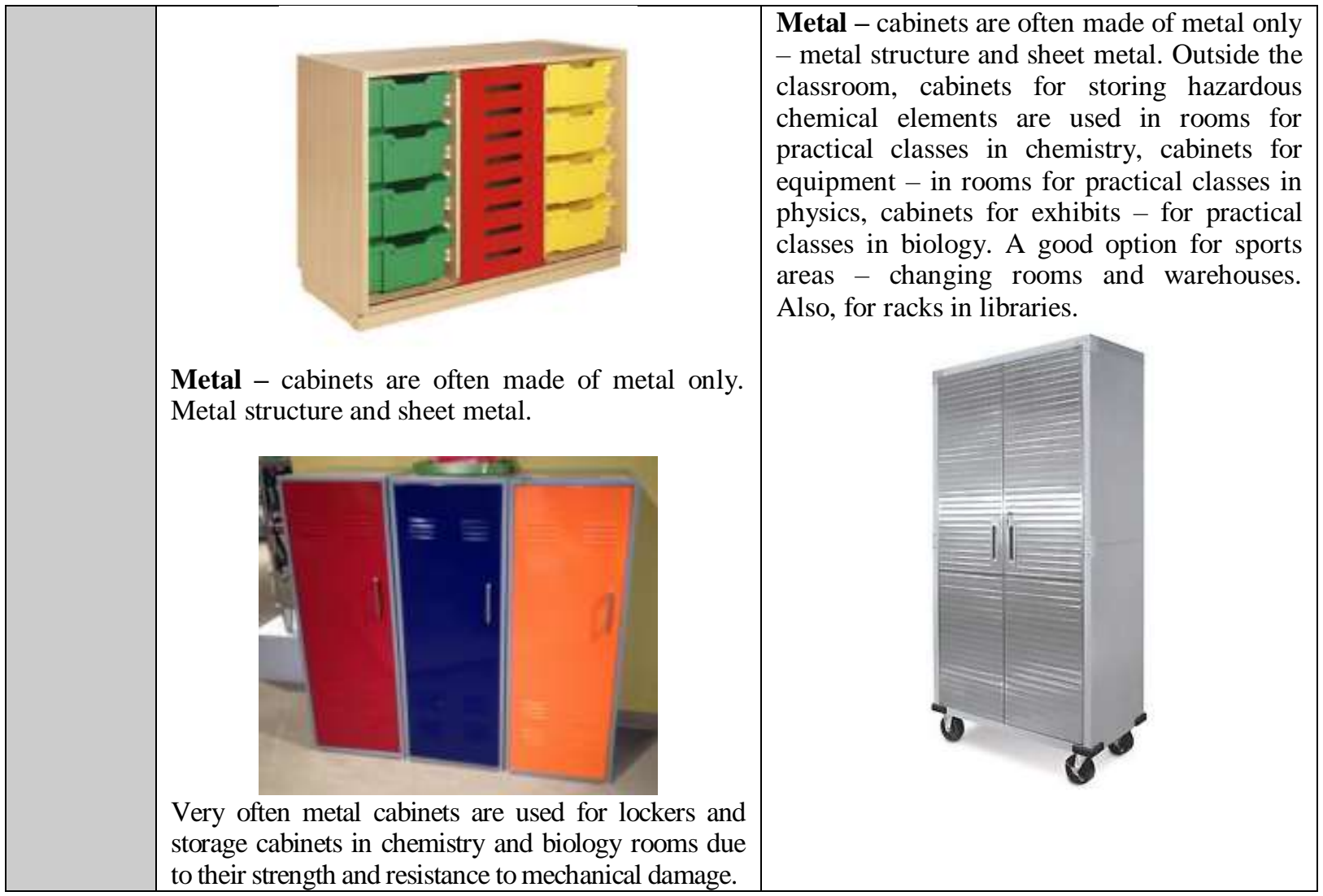

\section{- New ideas for mobility and multifunctionality of furniture}

In view of the modern way of teaching and the pursuit of working in groups in order to enhance the communicativeness of children, development of logical thinking, the stationary places and tables well-ordered in rows are outdated. Classroom furnishing should seek the possiblity for mobility and various grouping of furniture. Designers are looking for the opportunity to design a unit of furniture /table + chair/ to fit perfectly to every student, to be comfortable for writing and sitting, to have enough space for his/her personal effects.

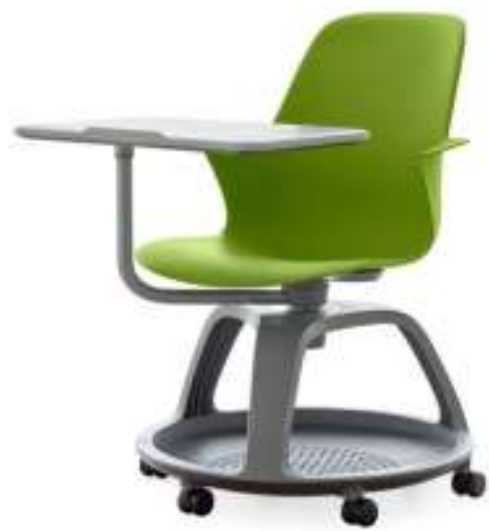

Fig.4. Single piece of furniture /table + chair/

Node High-Back Desk Chair - Tripod Base with Worksurface Steelcase /Photo published on the Internet/

This applies primarily to the secondary and high education classes, where the interior is considerably simpler, cleared from excessive decoration and unnecessary items. 

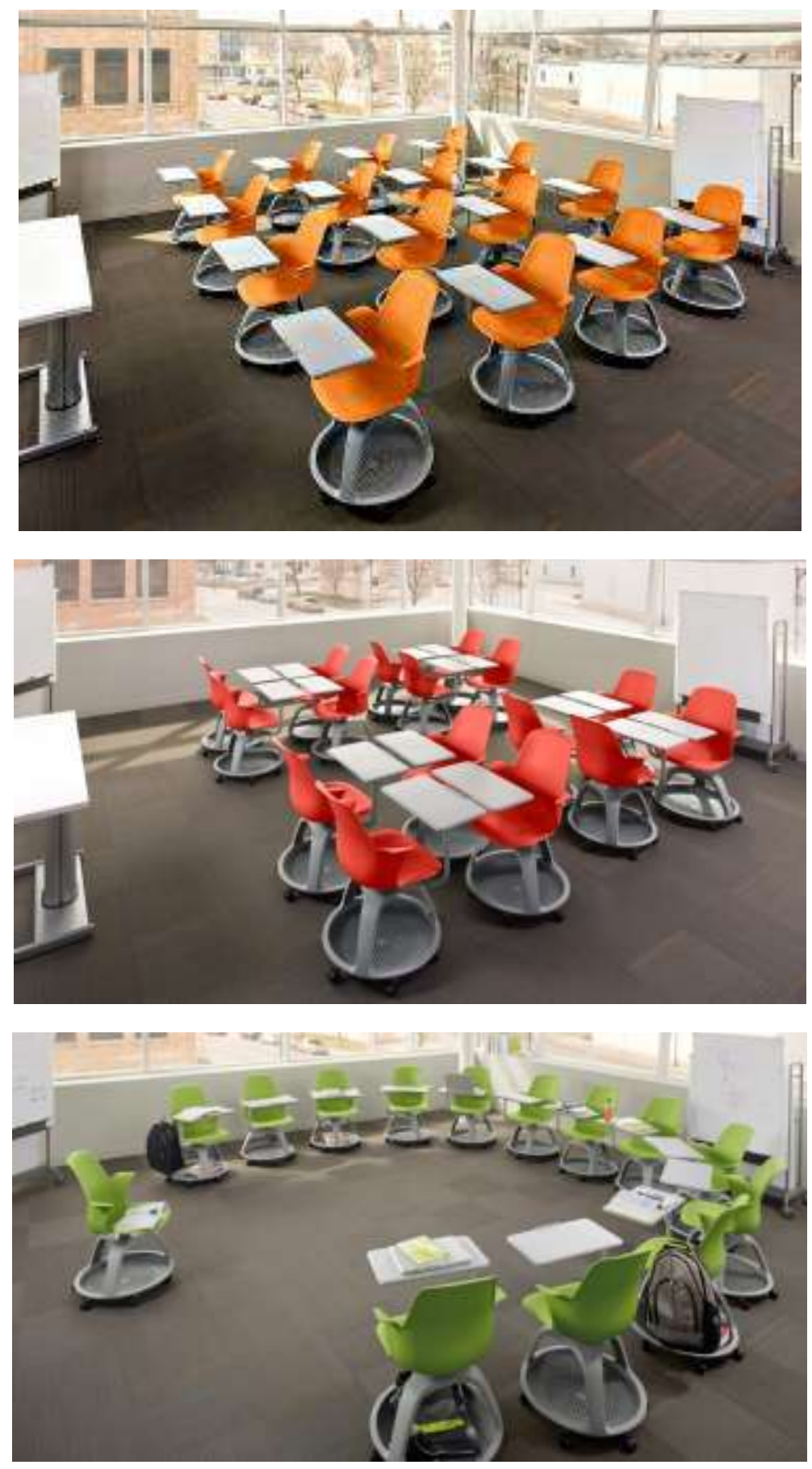

Fig.5. Arrangement options based on Mobile Furniture for secondary and high education classes /Photos published on the Internet/

All principles of ergonomics based on standards related to the size of children in the initial age groups are applicable, but here is an opportunity for more freedom in the design of classroom furniture. It is relied on mobile, light, one-seat furniture /desks/ or a chair and table for two, which may be easily grouped into interesting combinations. It is always emphasized on colourful solutions, robust materials and rounded edges of the finished product to make it as safe as possible. Many companies and designers from around the world are working to create the most comfortable, light and durable furniture for multifunctional use. 


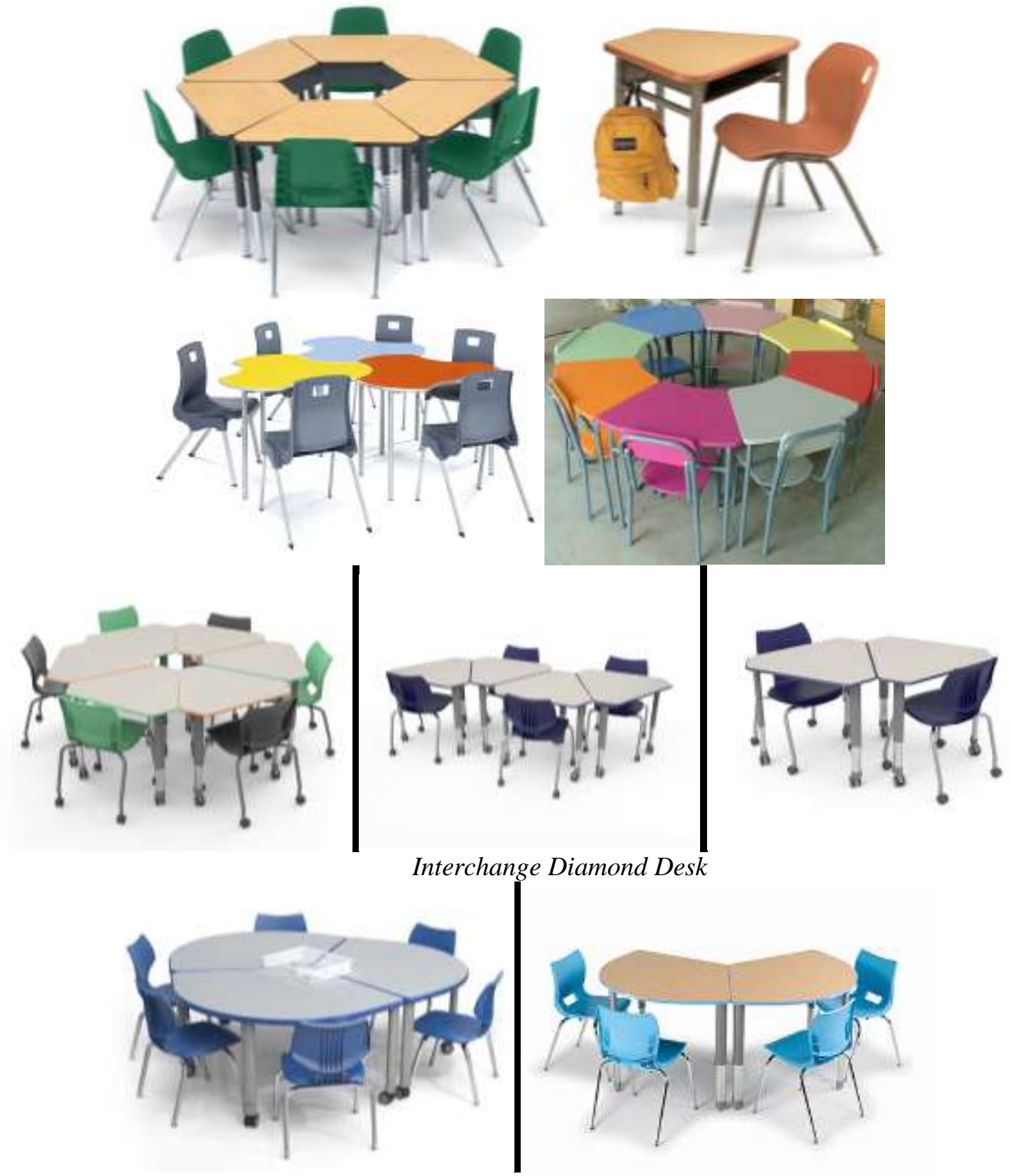

Smith System - This versatile, contemporary desk designed for collaborative learning provides sleek looks and solid functionality. The two-student desks can be arranged in many ways for both individual and group learning. Its large work surface provides ample space for two students doing work of all kinds.
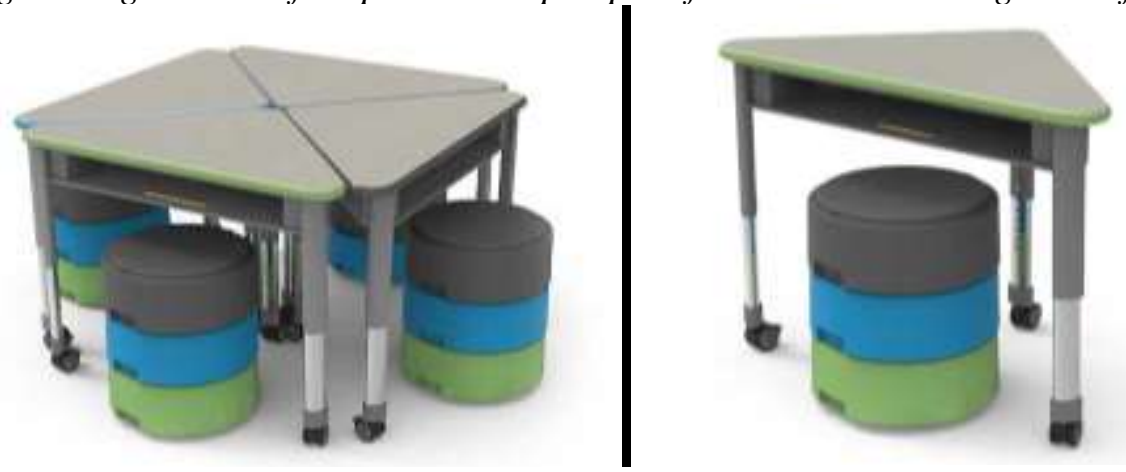

Smith System - Interchange Wing Open Front Desk

Fig.6. Examples of single tables with an option for different combinations/Photos published on the Internet/ 
In the primary education classroom there may be different areas to be furnished differently. The learning area may be furnished with desks, the practical activity area may be furnished with tables for group work, the listening and conversation area may have soft pillows on the floor. The furniture may include one item /table with a chair/, which is suitably related and combined with others to obtain different options in the different zones.

Multifunctional furniture is increasingly being introduced in the school buildings interior. These are light, comfortable, with many application options. Designers are seeking for more compact furniture to store various items and take less space. The main objective is to find a way to facilitate the work of students and teachers, and to allow for different combinations of furniture for work in two or in groups. This changes and diversifies the learning process and increases the interest and strengthens students' attention. To achieve multiple combinations, furniture should be light and allow for variations in the arrangement, and finally yet importantly, it should not take too much space, which should not be at the expense of convenience and comfort.

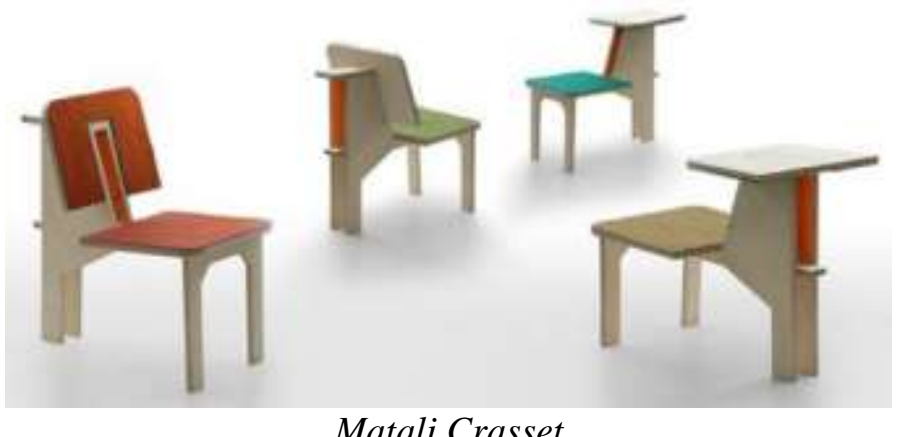

Matali Crasset

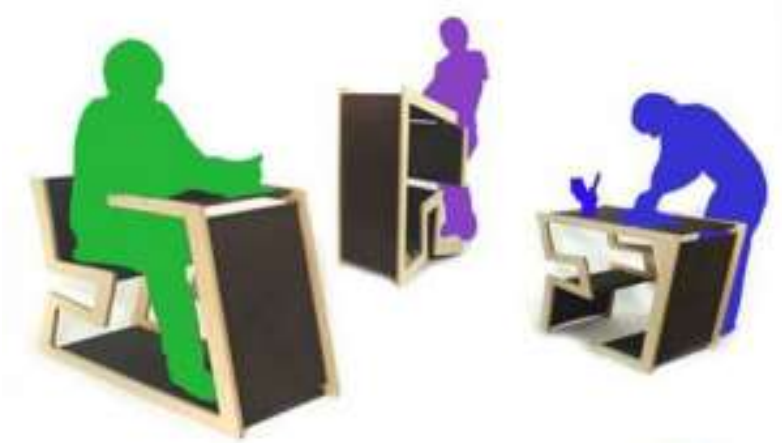

Design Mariu Goetzz - Design SPOTTER
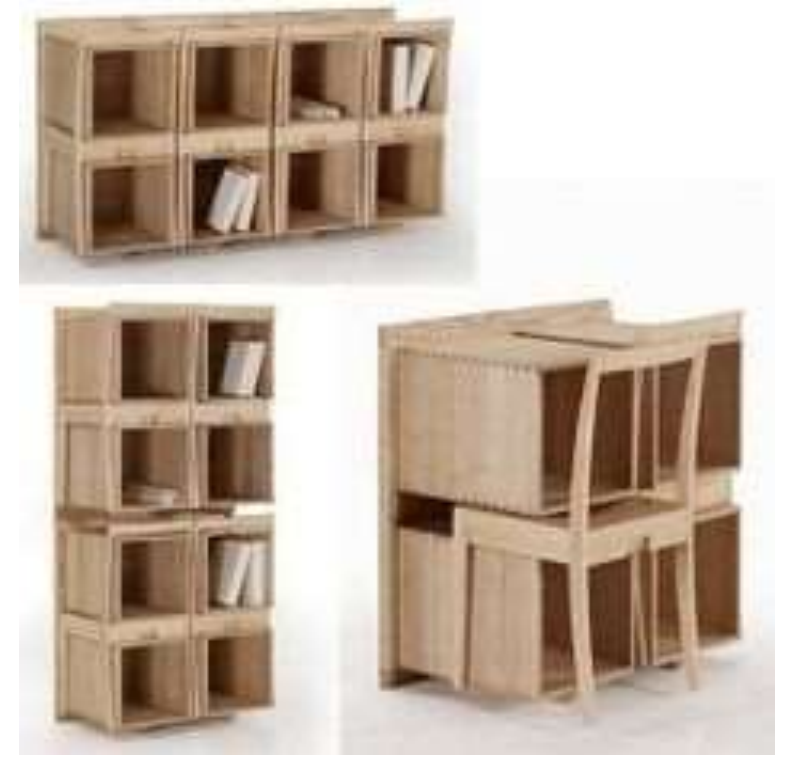

Fig.7. Examples of multifunctional furniture /Photos published on the Internet/ 
A great advantage in designing tables and chairs for schools is the possibility of changing the size of individual furniture. Children of the same age often have different size beyond standards, they are higher or overweight. It will be very good for them if they may adjust the chair and table in order to feel as comfortable as possible.

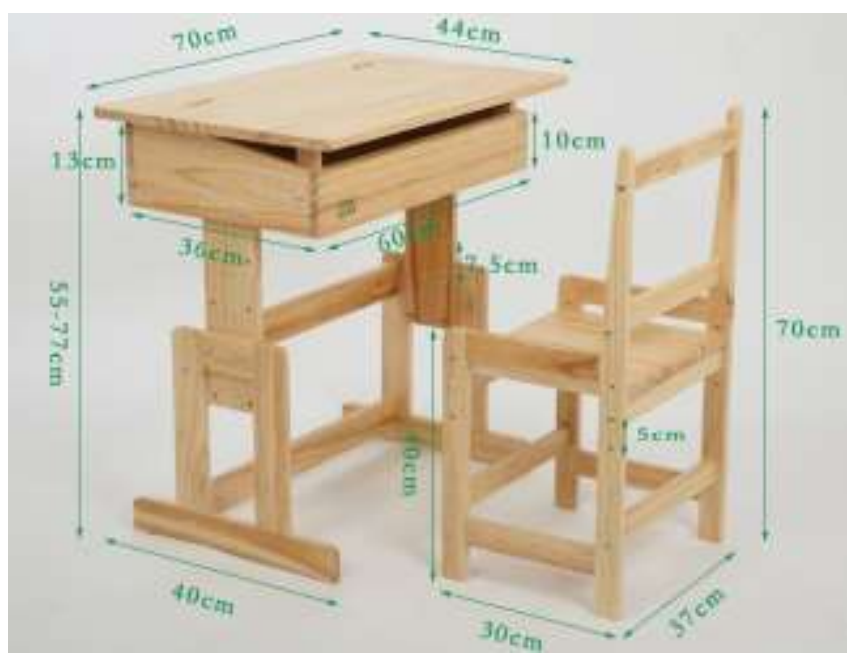

Fig.8. Option to adjust the height of the table and chair made of solid wood Photo published on the Internet

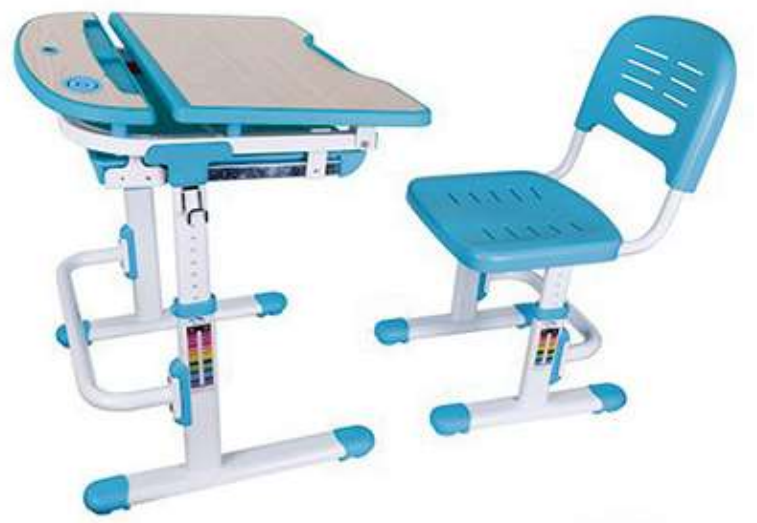

Fig.9. Option to adjust the height and the table and chair made of metal structures in combination with plastic /Photo published on the Internet/

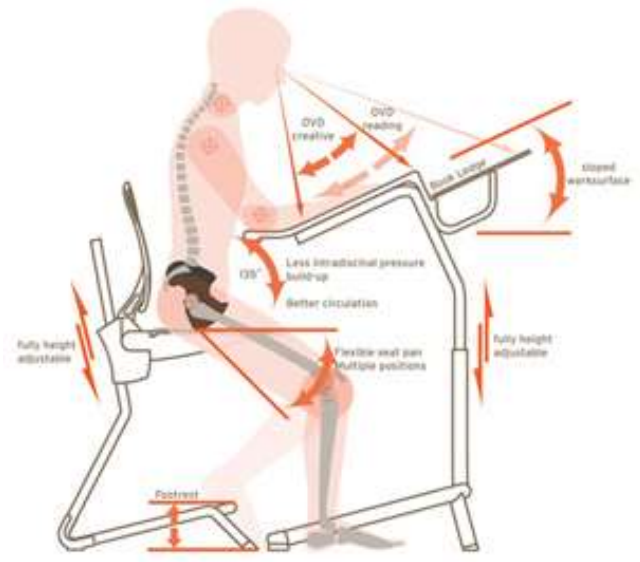

Flexible seat pan / fully heicht adfustable chair and desh

Fig.10. Mobility diagram for the individual elements of school furniture to allow for maximum comfort 
At best, the table and chair should allow for changing all parameters: height, seat angle, backrest angle, working plane angle, etc.

- Furniture concepts

Many designers work with the desire to design the most comfortable and functional school furniture. This is how many conceptual furniture models of the future are created.
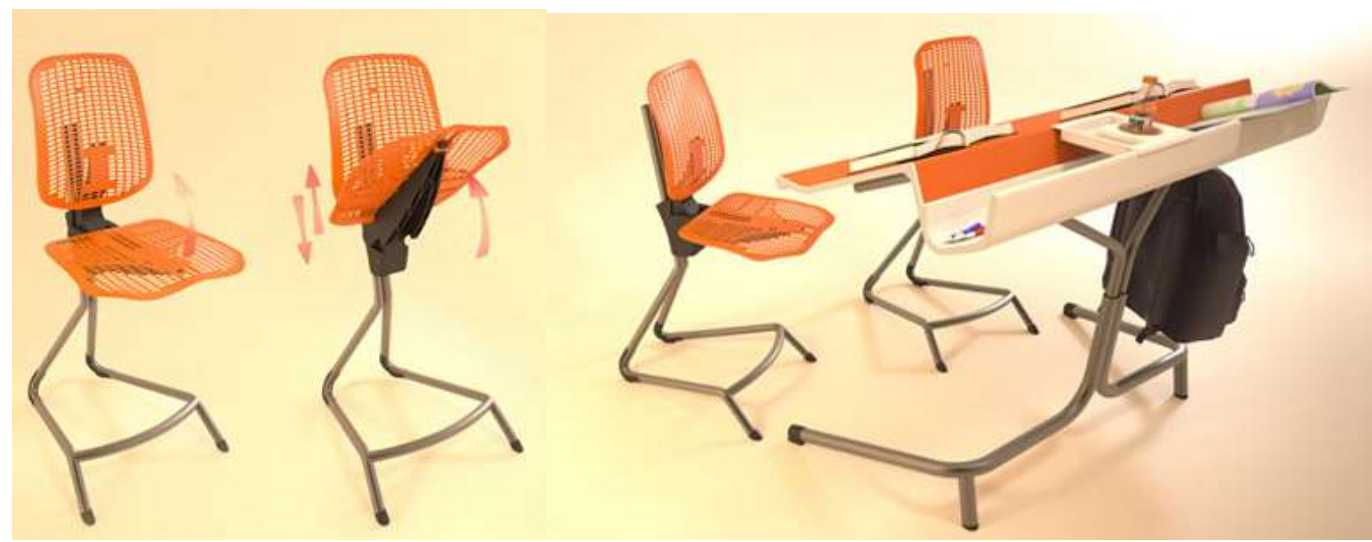

Maciek Wojcicki Design
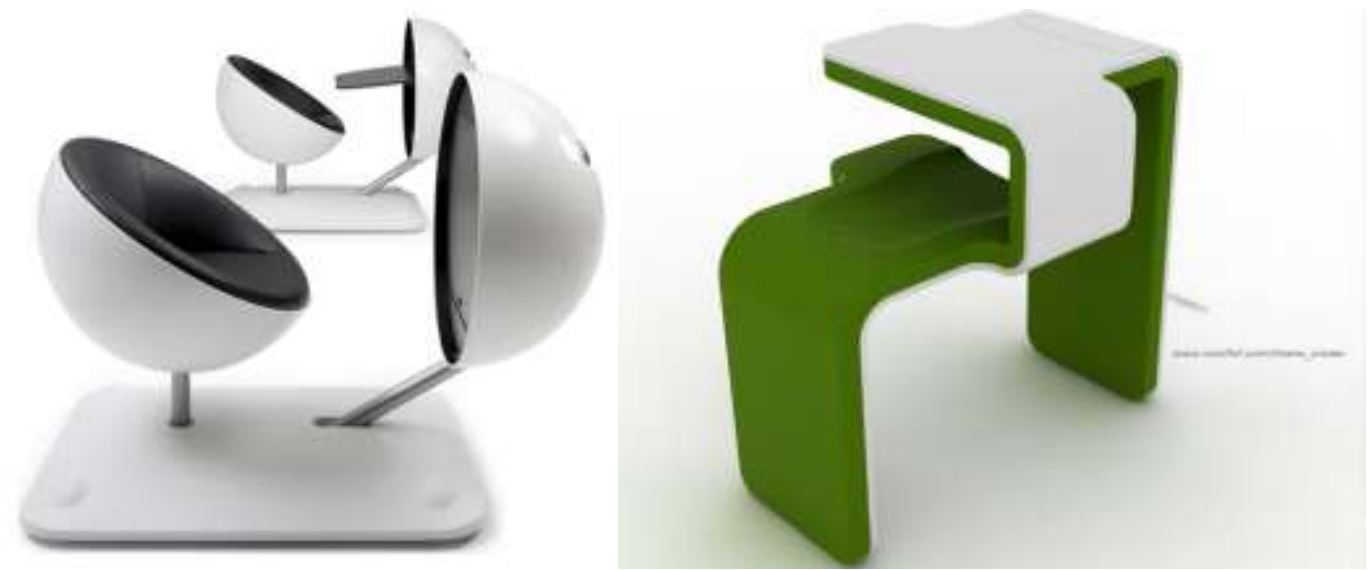

Flux e-desk

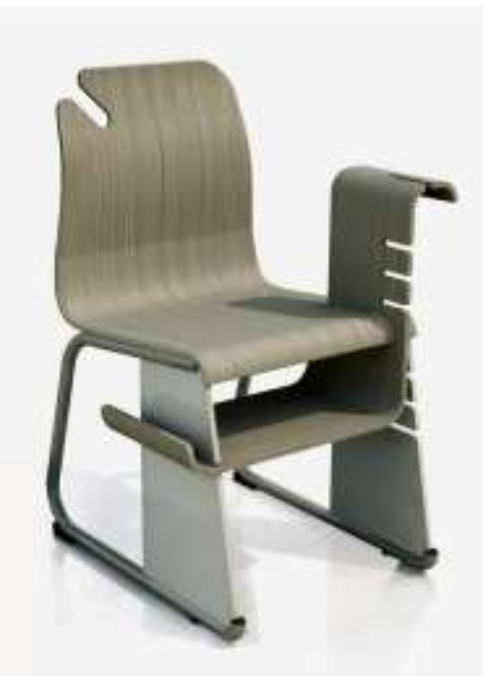

Behance Design

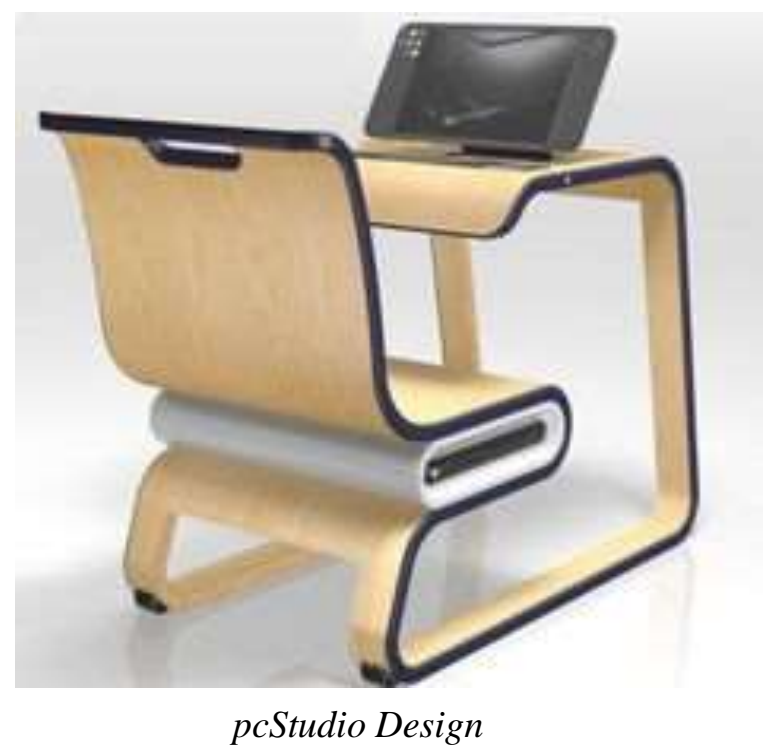

pcStudio Design

Fig.11. Conceptual models for school furniture /Photos published on the Internet/ 


\section{Conclusions.}

1. In practice there is no rule for the use of one or other material for the various elements of the interior. This is based on the designers' vision and feeling. Any combination is possible and would yield good results if well-considered and well synchronized with other elements of the environment light and space dimensions.

2. The youngest students need more "warmth" and coziness, and therefore natural materials and textiles are most often used for them.

3. Any materials may be used for middle and high education students. Children are grown up and for them a more stringent and "cold" setting would be more appropriate.

4. In order to make furniture, its ergonomics and size should be taken into consideration above all, depending on the age group of the children for whom it is intended.

5. Comfort is very important, but one should not forget the good look of furniture. It should have good colours and should look good.

6. The materials used must be durable, easy to clean and not harmful for children's health.

\section{REFERENCES}

1. Nair Prakash, Fielding Randall, The Language of School Design - Design Patterns for $21^{\text {st }}$ Century Schools, 2005;

2. William W. Caudill, Toward Better School Design, 1954;

3. Hristina Choparova, Acoustics in the Classroom, http://repporter.com, March 19 $9^{\text {th }}, 2013$

4. Naiden Chakarov, PhD, Zhecho Atanassov, PhD, History of Pedagogy, 1975;

5. G. D. Pirgov, St. Zhelev, Children's Educational Psychology

6. Ivanova Elitsa, School Building Interior, 2016 